\title{
Y-box binding protein 1 is up-regulated in proliferative breast cancer and its inhibition deregulates the cell cycle
}

\author{
YING-NAN YU ${ }^{1}$, GEORGE WAI-CHEONG YIP ${ }^{1}$, PUAY-HOON TAN ${ }^{1,2}$, AYE AYE THIKE ${ }^{2}$, \\ KEN MATSUMOTO $^{3}$, MASAFUMI TSUJIMOTO ${ }^{3}$ and BOON-HUAT BAY ${ }^{1}$ \\ ${ }^{1}$ Department of Anatomy, Yong Loo Lin School of Medicine, National University of Singapore; \\ ${ }^{2}$ Department of Pathology, Singapore General Hospital, Singapore; ${ }^{3}$ Laboratory of Cellular Biochemistry, \\ Institute of Physical and Chemical Research (RIKEN), Wako, Japan
}

Received March 4, 2010; Accepted April 27, 2010

DOI: 10.3892/ijo_00000697

\begin{abstract}
The Y-box-binding protein 1 (YB-1), a member of the cold-shock domain RNA-and DNA-binding protein family, has pleiotropic functions such as regulation of the cell cycle. The aim of this study was to evaluate if YB- 1 is a proliferative marker in breast cancer and elucidate potential downstream targets involved in YB-1-mediated cell cycle regulation using RNA interference technology. YB-1 protein expression was evaluated in tissue microarrays of 131 breast invasive ductal carcinomas by immunohistochemistry, while the YB-1 gene expression profile was evaluated in the T-47D, MDA-MB-231, ZR-75-1 and MCF7 breast cancer cell lines. Silencing of the $Y B-1$ gene in T-47D breast cancer cells was performed using siRNA and the effects of down-regulation of YB-1 on cell growth and regulation of the cell cycle were ascertained. A focused panel of 84 genes involved in cell cycle progression was also examined. In tissue microarrays, YB-1 expression was shown to be associated with proliferating cell nuclear antigen (PCNA) immunostaining. siRNA-mediated silencing of the $Y B-1$ gene inhibited cell proliferation and induced G1 phase cell cycle arrest in T-47D breast cancer cells. Knockdown of the $Y B-1$ gene induced up-regulation of two genes which contribute to G1-arrest (RAD9A and CDKN3 genes) and down-regulation of ten genes associated with positive regulation of the cell cycle (SKP2, SUMO1, ANAPC4, $C C N B 1, C K S 2, M N A T 1, C D C 20, R B B P 8, K P N A 2$ and $C C N C$ genes). The data obtained from the tissue microarrays and cell lines provide evidence that YB-1 is a reliable marker of cell proliferation and possibly a potential molecular target in breast cancer therapy.
\end{abstract}

Correspondence to: Dr B.H. Bay, Department of Anatomy, Yong Loo Lin School of Medicine, National University of Singapore, 4 Medical Drive, MD10, S 117 597, Singapore

E-mail: antbaybh@nus.edu.sg

Key words: Y-box binding protein, breast cancer, cell proliferation, cell cycle, siRNA

\section{Introduction}

Breast cancer is the most frequent malignancy among women in Western countries. It is estimated that more than 1.1 million new breast cancer cases are diagnosed worldwide per year (1). Identification of clinically useful biomarkers is imperative for optimal care and management of breast tumors (2). Several proteins such as estrogen receptors, epidermal growth factor receptors, BRCA1 and progesterone receptors have been reported to be prognostic biomarkers in breast cancer $(3,4)$.

Another potential biomarker which has been investigated in breast cancer is the Y-box binding protein 1 (YB-1) $(4,5)$. YB-1 belongs to a family of DNA- and RNA-binding proteins which participate actively in transcriptional and translational control of cells (5). It is a multifunctional protein involved in a myriad of functions which include gene regulation, DNA repair, drug resistance and cellular response to environmental stimuli (6-8). YB-1 can promote tumor growth and chemoresistance by inducing growth-enhancing genes such as proliferating cell nuclear antigen (PCNA), DNA topoisomerase II $\alpha$, thymidine kinase, DNA polymerase a, EGFR, HER-2, and multidrug resistance-1 (MDRI/ABCA1) (9-13).

Increased expression of YB-1 has been reported in a variety of cancers including primary breast cancer (9), prostate cancer (14), primary melanoma (15), colorectal cancer (12) and osteosarcoma (16). Overexpression of YB-1 has been reported in breast cancer carcinomas (9) and $80 \%$ of primary breast tumors were reported to show an increased copy number of chromosome 1, the location of $Y B-1$ (17). Futhermore, YB-1 has also been reported to stimulate proliferation of preneoplastic breast cancer cells (18) and phosphorylation of the protein at Ser102 in its cold shock domain by Akt has been observed to influence tumor cell growth (19). It has also been shown that YB-1 can bind EGFR and transcriptionally induce the expression of EGFR (20). Recent studies showed that expression of YB-1 is involved in Twist-promoted tumor cell growth (21) and tumor growth is suppressed by targeting YB-1 in nude mice (22). These previous findings suggest that YB-1 could possibly be a biomarker for proliferation in breast cancer.

Thus, in this study we analyzed the association of YB-1 expression with PCNA immunostaining in breast cancer 
tissue samples by immunohistochemistry and showed that increased YB-1 expression is associated with cell proliferation. We also observed that siRNA-mediated down-regulation of YB-1 expression altered cell cycle progression and the profile of cell cycle-related genes in breast cancer cells in vitro.

\section{Materials and methods}

Clinical samples. Tissue microarrays comprising 131 invasive ductal breast cancer specimens were obtained from the Singapore General Hospital between 1998 and 2002. Patients received primary surgical treatment (either mastectomy or breast conserving surgery). Ethics approval was obtained from the Institutional Review Board, Singapore General Hospital.

Immunohistochemistry. Tissue microarray sections were deparaffinized, rehydrated and incubated with $3 \%$ hydrogen peroxide for $15 \mathrm{~min}$ to quench endogenous peroxidase. Antigen retrieval was performed by heating sections in $10 \mathrm{mM}$ citrate buffer ( $\mathrm{pH}$ 6.0) for $15 \mathrm{~min}$. After rinsing thrice with phosphatebuffered saline-Triton X (PBS-TX), sections were blocked with $5 \%$ normal goat serum for $1 \mathrm{~h}$ at room temperature. The tissue sections were then incubated with rabbit polyclonal anti-YB-1 antibody (1:250 dilution) and mouse monoclonal anti-PCNA antibody (Sigma-Aldrich, St. Louis, MO; 1:200 dilution) at $4^{\circ} \mathrm{C}$ overnight, respectively. The anti-YB-1 antibody was raised in a rabbit by injecting a synthetic peptide K13 containing a sequence which corresponds to the N-terminus of human YB-1 protein (23). After washing with PBS-TX, biotinylated secondary antibody (1:200 dilution) was added and incubated for $1 \mathrm{~h}$ at room temperature. The staining was visualized by the avidin-biotin-complex technique (ABC Kit, Vector Laboratories, Burlingame, CA), using diaminobenzidine (DAB) as the substrate. The sections were counterstained with hematoxylin. The intensity of cytoplasmic YB-1 staining was scored as 0 (no detectable staining), 1+ (light staining), 2+ (moderate staining) and $3+$ (strong staining). The immunoreactivity score (IRS) was computed by multiplying the different staining intensities with the percentage of each staining intensity. Immunostaining for PCNA was assessed by counting the percentage of cells with positive nuclear PCNA staining. Negative control sections omitting the primary antibody were included.

Cell culture. T-47D breast cancer cells, MDA-MB-231 breast cancer cells, ZR-75-1 breast cancer cells, and MCF7 breast cancer cells were obtained from the American Type Culture Collection (ATCC, Rockville, MD) and maintained in Dulbecco's modified Eagle's medium or RPMI medium containing $10 \%$ fetal bovine serum (HyClone Laboratories, Logan, UT) in a $37^{\circ} \mathrm{C}$ incubator with $5 \% \mathrm{CO}_{2}$.

Transfection with YB-1 siRNA. 5.0x10 ${ }^{4}$ cells (grown in 24-well culture dish) or $2.5 \times 10^{5}$ cells (grown in 6-well culture dish) were incubated in complete culture medium without antibiotics. After $24 \mathrm{~h}$, cells were transfected using Oligofectamine ${ }^{\mathrm{TM}}$ Reagent (Invitrogen, Carlsbad, CA) according to the manufacturer's instructions. Two YB-1-specific siRNA duplexes, siYB-1A and siYB-2A were obtained from Ambion (Austin,
TX). The siYB-1A and siYB-2A sequences were sense 5'GCA AAA UUA CCA GAA UAG Utt-3', antisense 5'-ACU AUU CUG GUA AUU UUG Ctg-3' and sense 5'-GCA GAC CGU AAC CAU UAU At 3', antisense 5' UAU AAU GGU UAC GGU CUG Ctg-3' respectively. After $8 \mathrm{~h}$ incubation, growth medium containing $30 \%$ serum was added and the medium was changed the following day. Subsequently, transfected cells were incubated in medium with $10 \%$ FBS for 48 or $72 \mathrm{~h}$ for further analysis.

Quantitative real-time RT-PCR. Total RNA of harvested cells was extracted using RNeasy Mini Kit (Qiagen, Hilden, Germany) and reverse transcribed to cDNA using SuperScript III 1st-Strand Synthesis System (Invitrogen) following manufacturer's protocols. The housekeeping gene glyceraldehyde3 -phosphate dehydrogenase $(G A P D H)$ mRNA expression level was used as a reference. $Y B-1$ and $G A P D H$ transcript levels were determined using QuantiTect SYBR Green Master Mix (Qiagen). Gene specific primers used for $Y B-1$ and GAPDH were 5'-AAG TGA TGG AGG GTG CTG AC3' for YB-1 forward primer, 5'-TTC TTC ATT GCC GTC CTC TC-3' for YB-1 reverse primer; and 5'-GAA GGT GAA GGT CGG AGT CAA CG-3' for GAPDH forward primer and 5'-TGC CAT GGG TGG AAT CAT ATT GG-3' for GAPDH reverse primer. The cycling parameters were performed as indicated: initial denaturation at $95^{\circ} \mathrm{C}$ for 15 min, followed by 45 cycles of denaturation at $94^{\circ} \mathrm{C}$ for 15 sec, annealing at $60^{\circ} \mathrm{C}$ for $25 \mathrm{sec}$, and elongation at $72^{\circ} \mathrm{C}$ for $12 \mathrm{sec}$. The specificities of YB-1 and GAPDH primers were confirmed by melting curve analysis and also electrophoresis of PCR products on a $2 \%$ agarose gel. Relative quantification was calculated using $\Delta \Delta \mathrm{C}_{\mathrm{T}}$ and $2^{-\Delta \Delta C \mathrm{~T}}$ method, where $\Delta C_{T}$ refers the difference between the $C_{T}$ values of the target gene and the housekeeping gene GAPDH.

Western blot analysis. Twenty micrograms of extracted proteins were separated by SDS-PAGE and transferred onto PVDF membrane. The primary antibodies used were rabbit polyclonal YB-1 (1:1000 dilution), rabbit polyclonal CDKN3 (1:1000 dilution, Abcam, Cambridge, UK), rabbit polyclonal RAD9A (1:100 dilution, Abcam) and mouse monoclonal B-actin (1:6000, Sigma-Aldrich). Specific binding with the appropriate secondary antibodies was detected by enhanced chemiluminescence (Amersham, Little Chalfont, UK). The relative protein expression level was determined by densitometry measurement of the band intensity and normalization with $\beta$-actin.

Cell proliferation assay. Cell proliferation was performed in a 24-well plate and conducted with MTS CellTiter $96^{\circledR}$ $\mathrm{AQ}_{\text {ueous }}$ Non Radioactive Cell Proliferation Assay (Promega, Madison, WI). MTS/PMS solution $(100 \mu \mathrm{l})$ was added to the siRNA transfected cells in a 24-well plate containing $500 \mu \mathrm{l}$ of fresh culture medium. The plate was then incubated for $4 \mathrm{~h}$ at $37^{\circ} \mathrm{C}$ in a humidified, $5 \% \mathrm{CO}_{2}$ atmosphere. The absorbance was read at $490 \mathrm{~nm}$ using an ELISA plate reader.

Growth curve analysis. The growth curve was obtained using alamarBlue (Invitrogen). Cells were seeded in 6-well plates and 

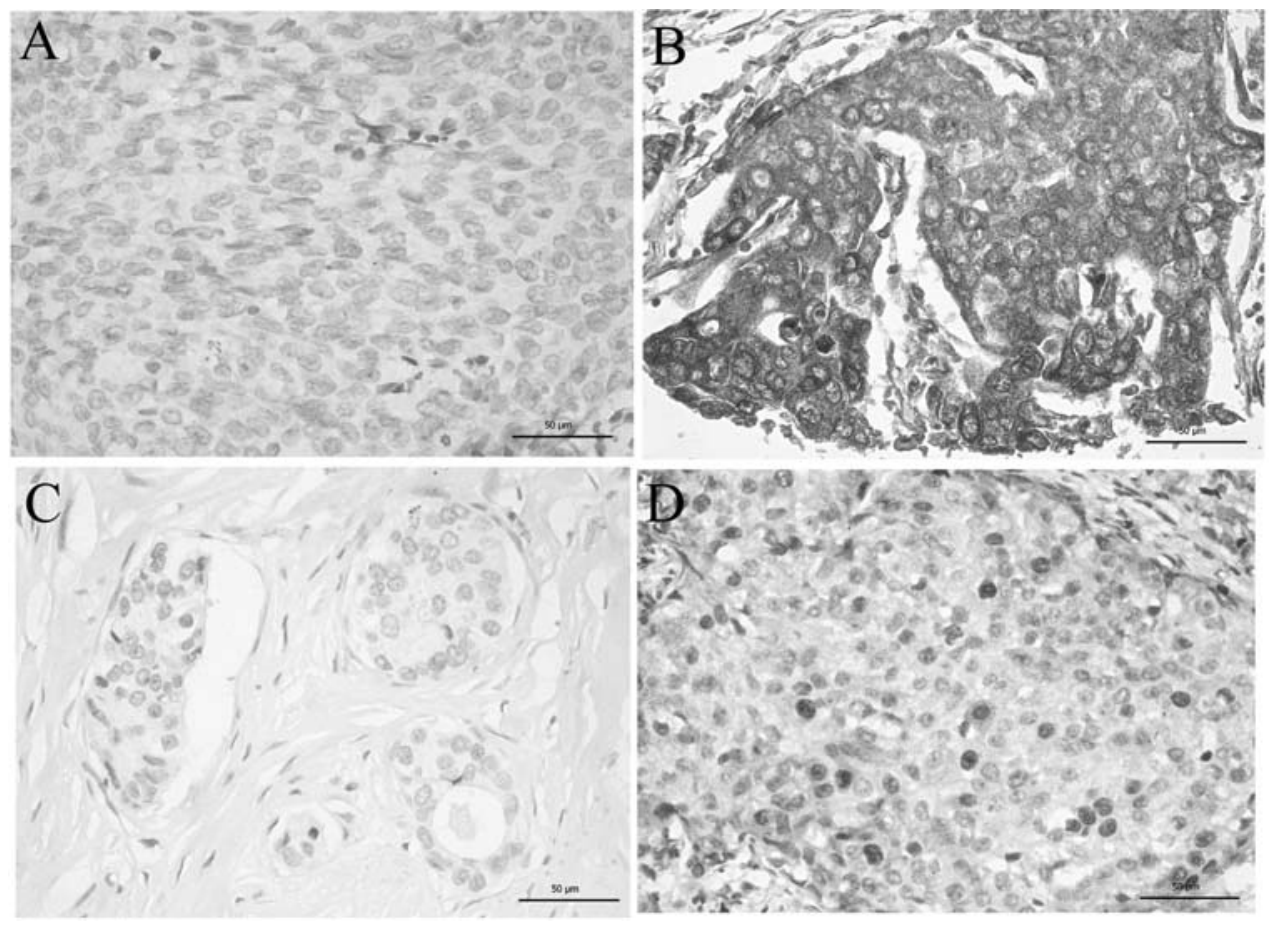

Figure 1. Immunohistochemical expression of YB-1 and PCNA in breast cancer. (A) Non-detectable YB-1 immunostaining in breast cancer tissue section. (B) Strong YB-1 (3+) immunostaining in breast cancer tissue section. (C) Negative PCNA staining in breast cancer tissue section. (D) Positive nuclear PCNA staining in breast cancer tissue section. Hematoxylin counterstain. Scale bars, $50 \mu \mathrm{m}$.

transfected with siRNA. After $20 \mathrm{~h}$, medium was removed and the wells were washed with PBS. AlamarBlue (1:10) in complete culture medium was added to each well and the plates were incubated for $4 \mathrm{~h}$ under normal growth conditions before the 24, 48, 72 and $96 \mathrm{~h}$ time-points. The absorbance readings were obtained at $570 \mathrm{~nm}$ wavelength with $600 \mathrm{~nm}$ as the reference wavelength.

Cell cycle analysis. Cell cycle assay was performed in triplicates and repeated thrice. Both floating and adherent cells were collected. Collected cells were fixed with $1 \mathrm{ml}$ of $70 \%$ icecold ethanol for at least $1 \mathrm{~h}$ at $4^{\circ} \mathrm{C}$. After washing twice with PBS, the cells were suspended in propidium iodide/RNase A solution and incubated for $30 \mathrm{~min}$ at room temperature before analysis.

Superarray analysis. The Human Cell Cycle RT ${ }^{2}$ Profiler $^{\mathrm{TM}}$ PCR Array (Superarray Bioscience, Frederick, MD) was utilized to examine the expression of various genes involved in cell cycle progression using cDNA of siNegative treated cells as the negative control at $48 \mathrm{~h}$ post transfection. Real-time PCR was performed using Superarray $\mathrm{RT}^{2}$ qPCR Master Mix according to the manufacturer's protocol. The experiments were performed in triplicates. The mean $\mathrm{C}_{\mathrm{T}}$ value for each gene in the siYB-1 treated versus siNegative treated group was determined and used to calculate the fold-change.

Statistical analysis. The SPSS software Version 12.0 for Windows was used for statistical analysis. Immunostaining of YB-1 was correlated with PCNA staining using Fisher's exact test. A two-tailed Student's t-test was performed for analysis of the statistical significance between two variables and the one-way ANOVA with post hoc test used for analysis
Table I. Correlation of YB-1 immunostaining with PCNA positivity.

$\begin{array}{cc}\text { YB- } 1 \text { staining } & \text { YB-1 staining } \\ \text { IRS } \leq 60 & \text { IRS }>60\end{array}$

\section{PCNA staining}

\begin{tabular}{llrr} 
Negative staining & 11 & 2 & 0.017 \\
Positive staining & 56 & 62 & \\
\hline
\end{tabular}

of three or more variables. A two-way ANOVA was used to compare statistical differences between growth curves. $\mathrm{p}<0.05$ was considered as statistically significant.

\section{Results}

$Y B-1$ expression correlates with cell proliferation in breast cancer tissues. The YB-1 protein was observed to be undetectable in $15(11.5 \%)$ patient samples and expressed in tumor cells from $116(88.5 \%)$ breast cancer patients (Fig. 1A and B). For the positive cases, YB-1 was found to be expressed in the cytoplasm of all tumor cells with absent or faint nuclear staining (Fig. 1B). PCNA nuclear immunostaining was absent in $13(9.9 \%)$ cases and positive in 118 cases (90.1\%) (Fig. 1C and D). For analyzing the correlation with PCNA staining, YB-1 immunostained samples with IRS $>60$ were considered as having high YB-1 expression and IRS $\leq 60$ as having low YB-1 expression. It was observed that breast cancer specimens with positive PCNA staining had a higher YB-1 expression compared to those with negative PCNA staining $(\mathrm{p}=0.017)$ (Table I). 


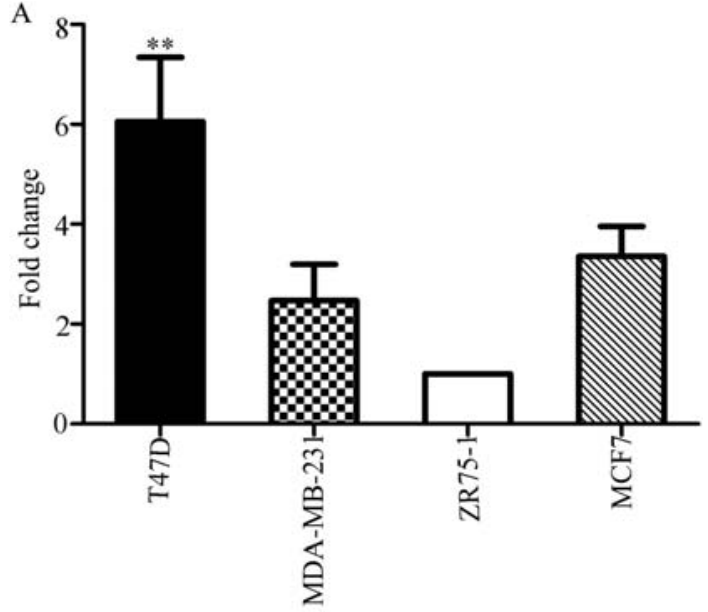

B

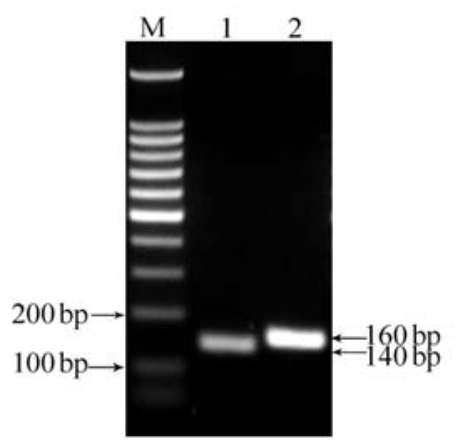

Figure 2. Differential expression of YB-1 in breast cancer cell lines. (A) Relative expression of YB-1 mRNA levels as determined by quantitative real-time RT-PCR in T47D, MDA-MB231, MCF7 and ZR-75-1 breast cancer cell lines. ZR75-1 breast cancer cell line was designated as the reference cell line and $G A P D H$ was used for normalization. Values are means of triplicates. Error bar, SEM. ${ }^{* *} \mathrm{p} \leq 0.001$. (B) Representative of gel electrophoresis of RT-PCR products of $Y B-1$ and housekeeping gene $G A P D H$. Lane designation: lane M, molecular weight marker; lane 1, YB-1; lane 2, GAPDH.

YB-1 mRNA is expressed in breast cancer cell lines. To further evaluate the role of YB-1 in cell proliferation, expression of $Y B-1$ mRNA was first determined in breast cancer cell lines. As shown in Fig. 2A, $Y B-1$ was found to be constitutively expressed in all the breast cell lines investigated. Using ZR-75-1 cells as the calibrator cell line, T-47D cells were found to have the highest $Y B-1$ expression $(\mathrm{p}<0.05)$. Hence, T-47D breast cancer cells were selected for silencing of the YB-1 gene with siRNA for further functional studies. The specificities of YB-1 and GAPDH primers were verified by melting curve analyses (not shown) and running the amplicons on a $2 \%$ gel (Fig. 2B).

Silencing of YB-1 gene in T-47D breast cancer cells reduces $Y B-1 \mathrm{mRNA}$ and protein expression. The knockdown efficiency of siYB-1A and siYB-1B at $48 \mathrm{~h}$ in T-47D cells were $87 \%$ and $81 \%$, respectively (Fig. 3A). Western blot analysis revealed a significant reduction in $\mathrm{YB}-1$ protein expression level in siYB-1 treated cells compared with siNegative treated cells (Fig. 3B). There was a 36\% (siYB-1A) and 48\% (siYB-1B) reduction of the $\mathrm{YB}-1$ protein in siYB-1 treated cells.

Silencing of YB-1 gene in T-47D breast cancer cells inhibits cell proliferation and deregulates cell cycle. siYB-1A and

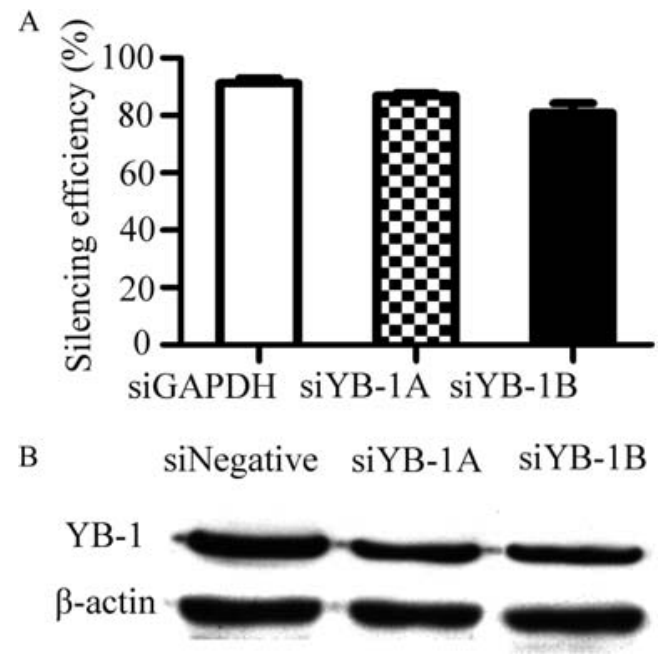

Figure 3. Silencing the $Y B-1$ gene down-regulates YB-1 expression at mRNA and protein levels. (A) Silencing efficiency of $Y B-1$ by siYB-1A and siYB-1B as analyzed by real-time RT-PCR in T-47D breast cancer line. siGAPDH was used as a positive control to optimize transfection conditions. (B) Down-regulation of YB-1 protein in T-47D cells as shown by Western blotting after silencing of the $Y B-1$ gene. B-actin was used as a normalizer. siYB-1 treatment resulted in $35-50 \%$ protein down-regulation.

siYB-1B treatment induced a decrease in cell proliferation at $48 \mathrm{~h}$ post-transfection (Fig. $4 \mathrm{~A} ; \mathrm{p}=0.050$ and $\mathrm{p}=0.047$, respectively). This result was mirrored by the growth curve analysis which showed a significant decline in cell growth in siYB-1A and siYB-1B treated cells compared with siNegative treated cells (Fig. 4B; $p=0.043$ and 0.024 , respectively). There was no significant difference in growth in siYB-1A versus siYB-1 treated cells $(\mathrm{p}=0.428)$. Cell cycle analysis revealed that there was an increase in the number of cells in G1 phase and decrease in the $\mathrm{S}$ and $\mathrm{G} 2 / \mathrm{M}$ phases in T-47D cells treated by both YB-1 specific siRNA duplexes at $48 \mathrm{~h}$ and $72 \mathrm{~h}$ post-transfection (Fig. 4C and D). At $48 \mathrm{~h}$ post-transfection, $Y B-1$ siRNA treatment induced significant increase in $\mathrm{G} 1$ cell fraction as compared to negative control siRNA treated cells, (siYB-1A: 75.8 vs. $63.6 \%, \mathrm{p}=0.0004$; siYB-1B: 76.4 vs. $63.6 \%, p=0.0003)$. This increase was accompanied by a concomitant reduction in the $\mathrm{S}$ phase (siYB-1A: 9.0 vs. $11.5 \%, \mathrm{p}=0.004$; siYB-1B: 8.6 vs. $11.5 \%$, $\mathrm{p}=0.006$ ) and $\mathrm{G} 2 / \mathrm{M}$ phase cell fraction (siYB-1A: 15.2 vs. $24.5 \%, \mathrm{p}=0.001$; siYB-1B: 14.9 vs. $24.5 \%$, $\mathrm{p}=0.001$ ). Similar alterations in the phases of the cell cycle were also observed in T-47D cells $72 \mathrm{~h}$ after transfection.

Silencing the YB-1 gene modulates expression of cell cyclerelated genes. To have a better insight into the role of YB-1 on cell proliferation, the expression profile of a focused panel of 84 cell cycle related genes known to either positively or negatively regulate the cell cycle was analyzed. Expression of 12 genes was found to be significantly altered after $48 \mathrm{~h}$ treatment with siYB-1 (Table II and Fig. 5A). Two genes, cyclin-dependent kinase inhibitor 3 (CDKN3) and RAD9 homolog $A$ (RAD9A), were up-regulated by 1.62 - and 2.60 -fold, respectively while the other 10 genes were down-regulated in response to siYB-1 treatment (SKP2: 1.33-fold; SUMO1, 1.11-fold; ANAPC4, 1.46-fold; CCNB1, 1.35-fold; $C K S 2$, 
A

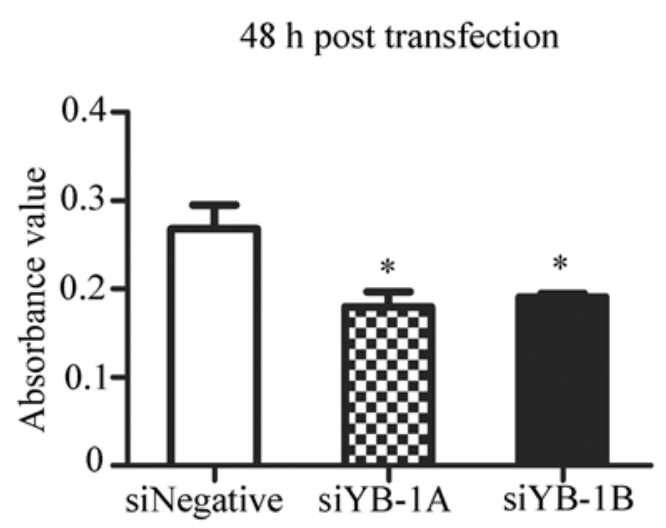

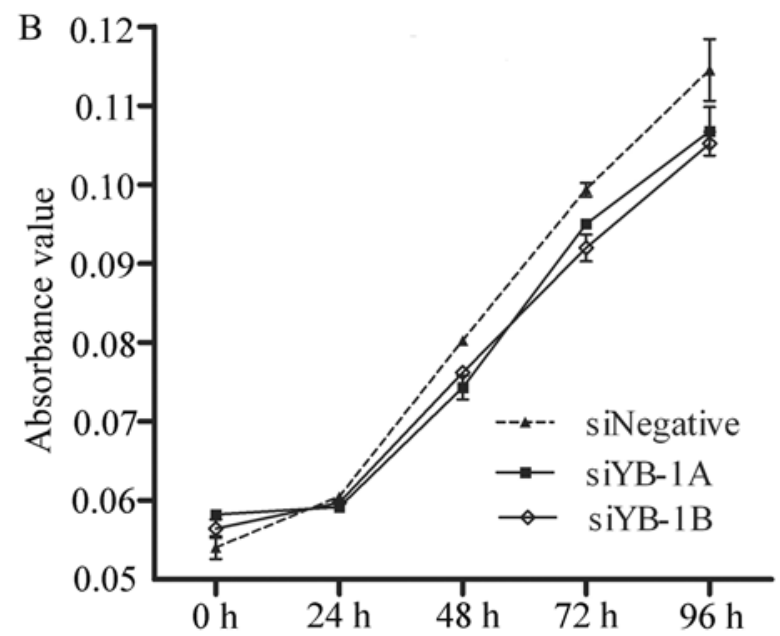

$\mathrm{C}$

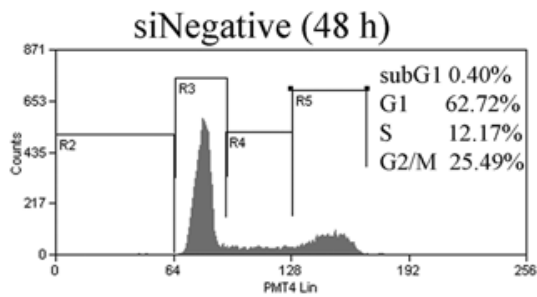

siNegative $(72 \mathrm{~h})$

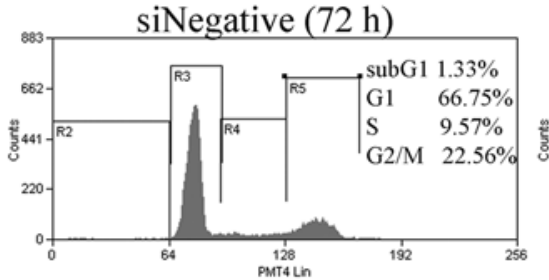

D

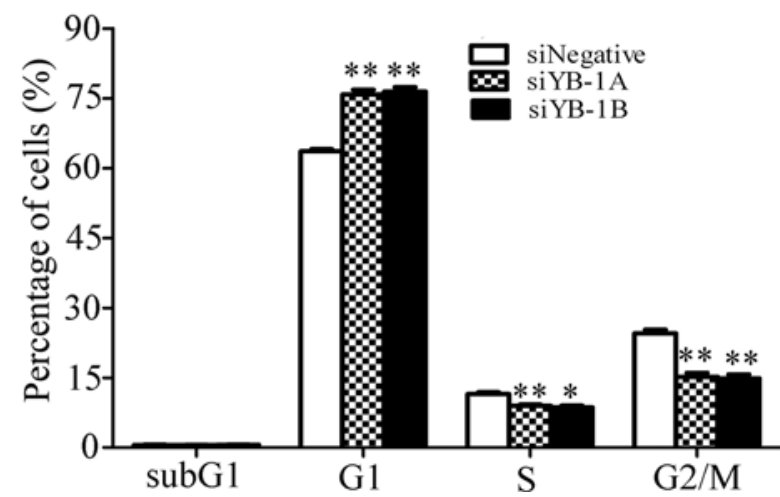

siYB-1A (48 h)

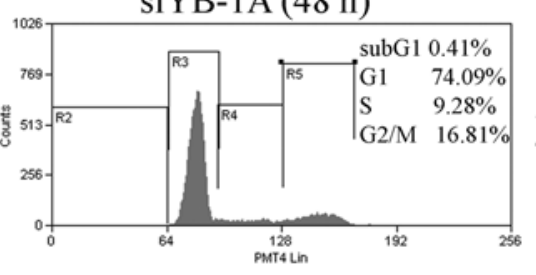

$\operatorname{siYB}-1 \mathrm{~A}(72 \mathrm{~h})$

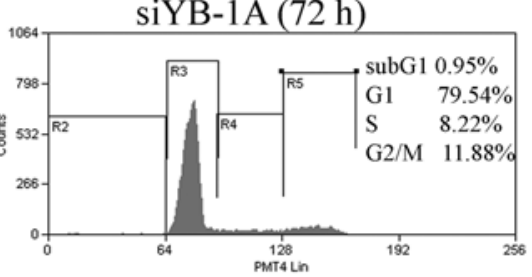

siYB-1B (48 h)

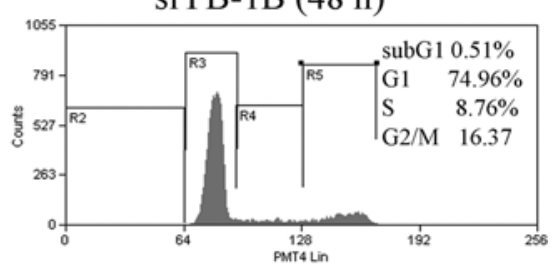

siYB-1B (72 h)

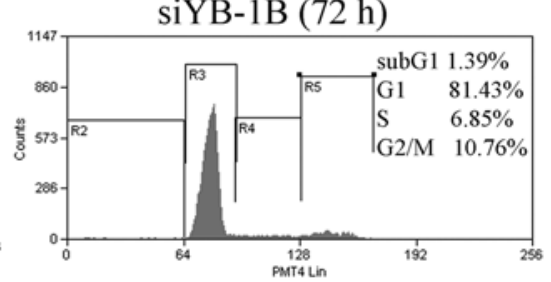

$72 \mathrm{~h}$ post transfection

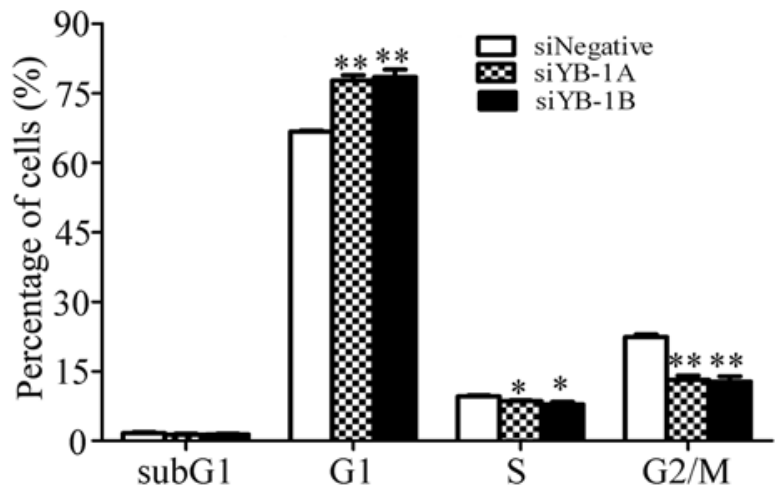

Figure 4. Silencing the $Y B-1$ gene reduces proliferation and alters cell cycle progression in T-47D breast cancer cells. (A) Cell proliferation assay was performed in T-47D cells at $48 \mathrm{~h}$ post-transfection with either siNegative or siYB-1. (B) Growth curve of T-47D cells transfected with siNegative or siYB-1 monitored up to $96 \mathrm{~h}$ post-transfection. (C) Representative cell cycle profile of T-47D cells transfected with siNegative, siYB-1A or siYB-1 analyzed by flow cytometry at 48 and $72 \mathrm{~h}$ post-transfection. (D) Cell fractions in the different cell cycle phases for siNegative, siYB-1A or siYB-1B treated T-47D cells at 48 and $72 \mathrm{~h}$ post-transfection, respectively. Values are means of triplicates. Error bar, SEM. ${ }^{*} \mathrm{p} \leq 0.05,{ }^{* *} \mathrm{p} \leq 0.001$.

1.28-fold; KPNA2, 1.14-fold; MNAT1, 1.84-fold; CDC20, 1.38-fold; $R B B P 8,1.43$-fold and $C C N C, 1.18$-fold). Differential protein expression levels of CDKN3 and RAD9A were also verified by Western blotting as shown in Fig. 5B.

\section{Discussion}

YB-1 has been reported to be overexpressed in about $75 \%$ of breast cancer carcinoma and associated with poor survival and high rates of relapse in almost all breast cancer subtypes $(4,9)$. YB-1 also possesses growth-enhancing potential in various cancers by promoting cell proliferation through transcriptional regulation of relevant genes. Although two main regulators of cell cycle progression, cyclin $\mathrm{A}$ and cyclin B1, have been found to be associated with YB-1 (18), other potential key cell cycle-related genes mediated by YB-1 which affects breast cancer progression have not been determined. 
Table II. Focused panel of the cell cycle related genes analyzed.

\begin{tabular}{|c|c|c|c|}
\hline Gene & Description & Gene & Description \\
\hline$A B L 1$ & C-abl oncogene 1 , receptor tyrosine kinase & $C K S 1 B$ & $\mathrm{CDC} 28$ protein kinase regulatory subunit $1 \mathrm{~B}$ \\
\hline ANAPC2 & Anaphase promoting complex subunit 2 & $C K S 2^{\mathrm{b}}$ & CDC28 protein kinase regulatory subunit 2 \\
\hline$A N A P C 4^{\mathrm{b}}$ & Anaphase promoting complex subunit 4 & CUL1 & Cullin 1 \\
\hline DIRAS3 & DIRAS family, GTP-binding RAS-like 3 & CUL2 & Cullin 2 \\
\hline ATM & Ataxia telangiectasia mutated & CUL3 & Cullin 3 \\
\hline$A T R$ & Ataxia telangiectasia and $\operatorname{Rad} 3$ related & $D D X 11$ & $\begin{array}{l}\text { DEAD/H (Asp-Glu-Ala-Asp/His) box poly- } \\
\text { peptide } 11 \text { (CHL1-like helicase homolog, } \\
\text { S. cerevisiae) }\end{array}$ \\
\hline$B A X$ & BCL2-associated X protein & $D N M 2$ & Dynamin 2 \\
\hline$B C C I P$ & BRCA2 and CDKN1A interacting protein & $E 2 F 4$ & $\begin{array}{l}\text { E2F transcription factor 4, p107/p130- } \\
\text { binding }\end{array}$ \\
\hline$B C L 2$ & B-cell CLL/lymphoma 2 & $G A D D 45 A$ & $\begin{array}{l}\text { Growth arrest and DNA-damage-inducible, } \\
\text { alpha }\end{array}$ \\
\hline BIRC5 & Baculoviral IAP repeat-containing 5 (survivin) & $G T F 2 H 1$ & $\begin{array}{l}\text { General transcription factor IIH, polypeptide } 1 \\
62 \mathrm{kDa}\end{array}$ \\
\hline$B R C A l$ & Breast cancer 1 , early onset & GTSE1 & G-2 and S-phase expressed 1 \\
\hline$B R C A 2$ & Breast cancer 2, early onset & HERC5 & Hect domain and RLD 5 \\
\hline$C C N B 1^{\mathrm{b}}$ & Cyclin B1 & HUS1 & HUS1 checkpoint homolog (S. pombe) \\
\hline CCNB2 & Cyclin B2 & KNTCl & Kinetochore associated 1 \\
\hline$C C N C^{\mathrm{b}}$ & Cyclin C & $K P N A 2^{\mathrm{b}}$ & $\begin{array}{l}\text { Karyopherin alpha } 2 \text { (RAG cohort } 1 \text {, importin } \\
\text { alpha 1) }\end{array}$ \\
\hline CCNDI & Cyclin D1 & $M A D 2 L 1$ & MAD2 mitotic arrest deficient-like 1 (yeast) \\
\hline$C C N D 2$ & Cyclin D2 & $M A D 2 L 2$ & MAD2 mitotic arrest deficient-like 2 (yeast) \\
\hline CCNE1 & Cyclin E1 & MCM2 & $\begin{array}{l}\text { Minichromosome maintenance complex } \\
\text { component } 2\end{array}$ \\
\hline CCNF & Cyclin F & MCM3 & $\begin{array}{l}\text { Minichromosome maintenance complex } \\
\text { component } 3\end{array}$ \\
\hline CCNG1 & Cyclin G1 & MCM4 & $\begin{array}{l}\text { Minichromosome maintenance complex } \\
\text { component } 4\end{array}$ \\
\hline CCNG2 & Cyclin G2 & MCM5 & $\begin{array}{l}\text { Minichromosome maintenance complex } \\
\text { component } 5\end{array}$ \\
\hline $\mathrm{CCNH}$ & Cyclin $\mathrm{H}$ & MKI67 & $\begin{array}{l}\text { Antigen identified by monoclonal antibody } \\
\text { Ki-67 }\end{array}$ \\
\hline CCNT1 & Cyclin T1 & $M N A T 1^{\mathrm{b}}$ & $\begin{array}{l}\text { Menage a trois homolog } 1 \text {, cyclin } \mathrm{H} \text { assembly } \\
\text { factor (Xenopus laevis) }\end{array}$ \\
\hline CCNT2 & Cyclin T2 & MRE11A & $\begin{array}{l}\text { MRE11 meiotic recombination } 11 \text { homolog A } \\
\text { (S. cerevisiae) }\end{array}$ \\
\hline$C D C 16$ & Cell division cycle 16 homolog (S. cerevisiae) & $N B N$ & Nibrin \\
\hline$C D C 2$ & Cell division cycle $2, \mathrm{G} 1 \rightarrow \mathrm{S}$ and $\mathrm{G} 2 \rightarrow \mathrm{M}$ & PCNA & Proliferating cell nuclear antigen \\
\hline$C D C 20^{\mathrm{b}}$ & Cell division cycle 20 homolog (S. cerevisiae) & $R A D 1$ & RAD1 homolog (S. pombe) \\
\hline$C D C 34$ & Cell division cycle 34 homolog (S. cerevisiae) & $R A D 17$ & RAD17 homolog (S. pombe) \\
\hline$C D K 2$ & Cyclin-dependent kinase 2 & RAD51 & $\begin{array}{l}\text { RAD51 homolog (RecA homolog, E. coli) } \\
\text { (S. cerevisiae) }\end{array}$ \\
\hline CDK4 & Cyclin-dependent kinase 4 & $R A D 9 A$ & RAD9 homolog A (S. pombe) \\
\hline
\end{tabular}


Table II. Continued.

\begin{tabular}{|c|c|c|c|}
\hline Gene & Description & Gene & Description \\
\hline$C D K 5 R 1$ & $\begin{array}{l}\text { Cyclin-dependent kinase 5, regulatory } \\
\text { subunit } 1 \text { (p35) }\end{array}$ & $R B 1$ & Retinoblastoma 1 (including osteosarcoma) \\
\hline CDK5RAP1 & CDK5 regulatory subunit associated protein 1 & $R B B P 8^{\mathrm{b}}$ & Retinoblastoma binding protein 8 \\
\hline$C D K 6$ & Cyclin-dependent kinase 6 & $R B L 1$ & Retinoblastoma-like 1 (p107) \\
\hline$C D K 7$ & Cyclin-dependent kinase 7 & $R B L 2$ & Retinoblastoma-like 2 (p130) \\
\hline$C D K 8$ & Cyclin-dependent kinase 8 & $R P A 3$ & Replication protein $\mathrm{A} 3,14 \mathrm{kDa}$ \\
\hline$C D K N 1 A$ & $\begin{array}{l}\text { Cyclin-dependent kinase inhibitor 1A } \\
\text { (p21, Cip1) }\end{array}$ & SERTADl & SERTA domain containing 1 \\
\hline$C D K N 1 B$ & $\begin{array}{l}\text { Cyclin-dependent kinase inhibitor 1B } \\
\text { (p27, Kip1) }\end{array}$ & $S K P 2^{\mathrm{b}}$ & S-phase kinase-associated protein 2 (p45) \\
\hline$C D K N 2 A$ & $\begin{array}{l}\text { Cyclin-dependent kinase inhibitor 2A } \\
\text { (melanoma, p16, inhibits CDK4) }\end{array}$ & $S U M O 1^{\mathrm{b}}$ & $\begin{array}{l}\text { SMT3 suppressor of mif two } 3 \text { homolog } 1 \\
\text { (S. cerevisiae) }\end{array}$ \\
\hline$C D K N 2 B$ & $\begin{array}{l}\text { Cyclin-dependent kinase inhibitor 2B } \\
\text { (p15, inhibits CDK4) }\end{array}$ & $T F D P 1$ & Transcription factor Dp-1 \\
\hline$C D K N 3^{\mathrm{a}}$ & $\begin{array}{l}\text { Cyclin-dependent kinase inhibitor } 3 \text { (CDK2- } \\
\text { associated dual specificity phosphatase) }\end{array}$ & $T F D P 2$ & $\begin{array}{l}\text { Transcription factor } \mathrm{Dp}-2(\mathrm{E} 2 \mathrm{~F} \\
\text { dimerization partner } 2)\end{array}$ \\
\hline CHEK1 & CHK1 checkpoint homolog (S. pombe) & TP53 & Tumor protein $\mathrm{p} 53$ \\
\hline CHEK2 & CHK2 checkpoint homolog (S. pombe) & $U B A 1$ & Ubiquitin-like modifier activating enzyme 1 \\
\hline
\end{tabular}

${ }^{\mathrm{a}}$ Gene up-regulated; ${ }^{\mathrm{b}}$ gene down-regulated.
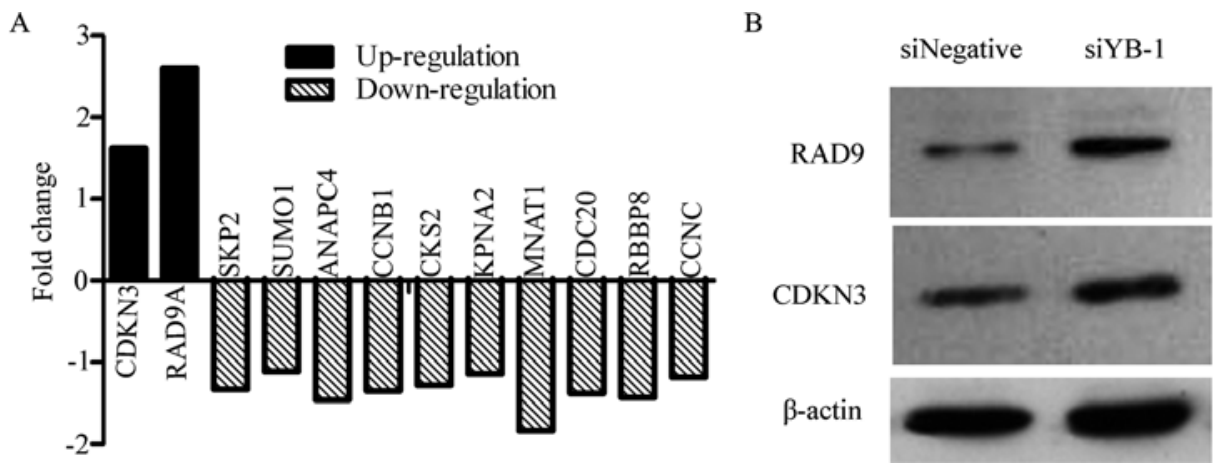

Figure 5. Silencing the $Y B-1$ gene in T-47D breast cancer cells modulates cell cycle-related genes. (A) Genes differentially expressed by silencing the $Y B-1$ gene $(\mathrm{p}<0.05)$. Values are obtained based on $\mathrm{C}_{\mathrm{T}}$ values of triplicates. (B) Silencing of $Y B-1$ gene induced up-regulation of CDKN3 and RAD9A proteins as analyzed by Western blotting. Representative blots of triplicate experiments.

The primary focus of this study was to identify a prognostic marker of cell proliferation and a promising molecular target in breast cancer therapy. In the present study, immunopositive staining of YB-1 in tissue microarray specimens was observed to be significantly associated with PCNA, an established marker of cell proliferation. The relationship between YB-1 expression and cell proliferation in tumor samples is substantiated by in vitro evidence where siRNA-mediated knock-down of the $Y B-1$ gene in T-47D breast cancer cells (which had the highest level of YB-1 expression of the four breast cancer cell lines examined) resulted in a significant decrease in cell growth compared to siNegative treated cells. Cell cycle analysis in T-47 D cells and MDA-MB231 cells revealed a significantly increased G1 cell fraction which was accompanied by a decrease in the $\mathrm{S}$ phase and $\mathrm{G} 2 / \mathrm{M}$ phase in siYB-1 treated cells compared to siNegative treated cells. To further investigate the underlying molecular basis that may contribute to observed alterations in the cell cycle, a Superarray analysis of 84 cell cycle-related genes was carried out in T-47D breast cancer cells. We identified the 
following genes that were modulated in YB-1-regulated cell cycle progression, viz., CDKN3, RAD9A, SKP2, SUMO1, ANAPC4, CCNB1, CKS2, MNAT1, CDC20, RBBP8, KPNA2 and $C C N C$. Among them, $C D K N 3$ and $R A D 9 A$ were found to be up-regulated at mRNA and protein levels involved in G1arrest, while the other 10 cell cycle genes were downregulated.

Cell cycle progression is mainly controlled by activation of cyclin-dependent kinases (CDKs) which regulates transition from one cell cycle phase to the next phase. CDKN3 encodes a kinase-associated phosphatase (KAP) which is an important regulator of cell cycle progression $(25,26)$. KAP selectively inhibits $\mathrm{Cdk} 2$ by dephosphorylating a threonine residue (Thr160), thereby reducing its ability to phosphorylate the retinoblastoma protein ( $\mathrm{pRb}$ ). Non-phosphorylated $\mathrm{pRb}$ binds transcription factor E2F1 and prevents generation of proteins required for G1/S transition (26-28). Hence, decreased cell proliferation observed with knockdown of YB-1 could be due in part to up-regulation of CDKN3. This is supported by the finding that mouse embryo cells with YB-1 deficiency express accumulated levels of the G1-specific CDK-inhibitors p16 ${ }^{\mathrm{INK} 4 \mathrm{a}}$ and $\mathrm{p} 21^{\mathrm{CIP}}$ and senesce prematurely (29).

Besides CDKN3, our results also show that YB-1 can control G1/S transition by regulating the expression of the RAD9A gene and protein. RAD9A (also known as RAD9) is evolutionarily conserved (30) and the encoded protein plays key roles in several fundamental biological processes including mediating the cell cycle $(31,32)$, acting as a proapoptotic element (33) and maintaining genomic integrity (34). It has been documented that RAD9A can bind RAD1 and HUS1, forming a checkpoint protein complex which is capable of recognizing DNA damage and delay cell cycle progression $(35,36)$. Like p53, RAD9A has been found to have the capability of controlling the progression of cells from $\mathrm{G} 1$ to $\mathrm{S}$ by activating transcription of $p 21$ gene (37), which encodes a potent cyclin-dependent kinase inhibitor (CKI), leading to G1-arrest. Beyond this, RAD9A is also involved in cell-cycle arrest in $\mathrm{G} 2 / \mathrm{M}$ phase and prevents entry into mitosis by inhibiting the nuclear division pathway which requires Cdc20 function (38), resulting in reduced cell growth (39). Cdc20 activates the anaphase-promoting complex/ cyclosome in mitosis which facilitates chromosome segregation (40). Taken together, si-YB1 mediated reduced cell growth could also be partially explained by up-regulation of RAD9A and concurrent down-regulation of $\mathrm{Cdc} 20$.

Our finding that the CCNB1 gene, which controls G2-M transition of the cell cycle by complexing with CDK1 (41), was inhibited by knockdown of YB-1 is in agreement with the previous finding that as a cell cycle stage-specific transcription factor, YB-1 facilitates cyclin Bl gene transcription (18). ANAPC4 drives metaphase-anaphase transition by ubiquitinating its specific substrates such as mitotic cyclins and anaphase inhibitor and facilitates cell cycle progression. CKS2 proteins are essential components of cyclin/cyclindependent kinase complexes involved in cell cycle regulation (42). Another down-regulated protein MNAT1 is involved in assembly of CDK-activating kinase (CAK) complex which phosphorylates and activates essential cell cycle regulators - CDKs (43). The S-phase kinase-associated protein Skp2 is required for the ubiquitin-mediated degradation of the $\mathrm{Cdk}$ inhibitor p27 which arrests cell cycle in G1 phase $(44,45)$. RBBP8 encodes CtIP, a phosphorylation-dependent binding partner of BRCA1 C-terminal domains and BRCA1/CtIP complex is required for $\mathrm{G} 2 / \mathrm{M}$ transition induced by DNA damage (46). The other three genes, including SUMO1, KPNA2 and $C C N C$, may not be biologically significant due to the slight fold changes $(<1.20)$.

Our present study has revealed that cell cycle-related genes regulated by YB-1 are involved in tumor growth, which is consistent with previous findings that down-regulation of YB-1 expression induced growth inhibitory effects associated with increased apoptosis $(18,21,22,47)$, although the underlying mechanisms governing YB-1-mediated cell growth are still not fully understood. It has been reported that YB-1 can be phosphorylated by Akt and promote tumor cell growth through Akt signal transduction pathway (19) and that Twist upregulates AKT2 (48) and induces tumor growth regulation of YB-1 (21). Lately, another G1/S phase protein, CDC6 which is essential for the initiation of DNA replication was also found to be modulated by YB-1 (49). However, factors influencing tumor growth may be more complex than it seems. Recently, it was reported that enforced YB-1 expression in H-ras transformed MCF 10AT breast epithelial cells promoted epithelial-mesenchymal transition accompanied by increased metastatic potential with reduced proliferation rates $(50)$.

In conclusion, we have demonstrated that there is a significant association between YB-1 and cell proliferation in both breast cancer tissues and in vitro. Moreover, cell cycle analysis revealed that YB-1 regulates cell cycle progression by modulating expression of 12 cell cycle-related genes. It would seem that regulation of the cell cycle by YB-1 requires a complex interplay of cell cycle related genes. YB-1 is a potentially clinically useful biomarker of proliferation in breast cancer and a promising molecular target for further development as a novel agent in breast cancer therapy.

\section{Acknowledgements}

This study was supported by the Singapore National Medical Research Council, Grants NMRC/1019/2005 (B.-H.B.) and NMRC/1081/2006 (B.-H.B.) and the Singapore Cancer Syndicate Grant MS0004R (P.-H.T). Y.-N.Y. is the recipient of a graduate research scholarship from the National University of Singapore.

\section{References}

1. Olopade OI, Grushko TA, Nanda R and Huo D: Advances in breast cancer: pathways to personalized medicine. Clin Cancer Res 14: 7988-7999, 2008.

2. Sawyers CL: The cancer biomarker problem. Nature 452 : 548-552, 2008.

3. Giancotti V: Breast cancer markers. Cancer Lett 243: 145-159, 2006.

4. Habibi G, Leung S, Law JH, Gelmon K, Masoudi H, Turbin D, Pollak M, Nielsen TO, Huntsman D and Dunn SE: Redefining prognostic factors for breast cancer: YB-1 is a stronger predictor of relapse and disease-specific survival than estrogen receptor or HER-2 across all tumor subtypes. Breast Cancer Res 10: R86, 2008.

5. Matsumoto K and Wolffe AP: Gene regulation by Y-box proteins: coupling control of transcription and translation. Trends Cell Biol 8: 318-323, 1998. 
6. Izumi $H$, Imamura $T$, Nagatani $G$, Ise $T$, Murakami $T$, Uramoto $H$, Torigoe T, Ishiguchi $\mathrm{H}$, Yoshida $\mathrm{Y}$, Nomoto M, Okamoto T, Uchiumi T, Kuwano M, Funa K and Kohno K: Y-box-binding protein-1 binds preferentially to single-stranded nucleic acids and exhibits $3^{\prime} \rightarrow 5^{\prime}$ exonuclease activity. Nucleic Acids Res 29: 1200-1207, 2001.

7. Kohno K, Izumi H, Uchiumi T, Ashizuka M and Kuwano M: The pleiotropic functions of the Y-box-binding protein, YB-1. Bioessays 25: 691-698, 2003.

8. Kuwano M, Uchiumi T, Hayakawa H, Ono M, Wada M, Izumi H and Kohno K: The basic and clinical implications of ABC transporters, Y-box-binding protein-1 (YB-1) and angiogenesis-related factors in human malignancies. Cancer Sci 94: 9-14, 2003.

9. Bargou RC, Jurchott K, Wagener C, Bergmann S, Metzner S, Bommert K, Mapara MY, Winzer KJ, Dietel M, Dorken B and Royer HD: Nuclear localization and increased levels of transcription factor YB-1 in primary human breast cancers are associated with intrinsic MDR1 gene expression. Nat Med 3: 447-450, 1997

10. En-Nia A, Yilmaz E, Klinge U, Lovett DH, Stefanidis I and Mertens PR: Transcription factor YB-1 mediates DNA polymerase alpha gene expression. J Biol Chem 280: 7702-7711, 2005.

11. Gu C, Oyama T, Osaki T, Kohno K and Yasumoto K: Expression of Y-box-binding protein-1 correlates with DNA topoisomerase IIalpha and proliferating cell nuclear antigen expression in lung cancer. Anticancer Res 21: 2357-2362, 2001.

12. Shibao K, Takano H, Nakayama Y, Okazaki K, Nagata N, Izumi $\mathrm{H}$, Uchiumi $\mathrm{T}$, Kuwano $\mathrm{M}$, Kohno $\mathrm{K}$ and Itoh $\mathrm{H}$ : Enhanced coexpression of YB-1 and DNA topoisomerase II alpha genes in human colorectal carcinomas. Int J Cancer 83: 732-737, 1999

13. Wu J, Lee C, Yokom D, Jiang H, Cheang MC, Yorida E, Turbin D, Berquin IM, Mertens PR, Iftner T, Gilks CB and Dunn SE: Disruption of the Y-box binding protein-1 results in suppression of the epidermal growth factor receptor and HER-2. Cancer Res 66: 4872-4879, 2006.

14. Gimenez-Bonafe P, Fedoruk MN, Whitmore TG, Akbari M, Ralph JL, Ettinger S, Gleave ME and Nelson CC: YB-1 is upregulated during prostate cancer tumor progression and increases P-glycoprotein activity. Prostate 59: 337-349, 2004.

15. Schittek B, Psenner K, Sauer B, Meier F, Iftner T and Garbe C: The increased expression of Y-box-binding protein 1 in melanoma stimulates proliferation and tumor invasion, antagonizes apoptosis and enhances chemoresistance. Int J Cancer 120: 2110-2118, 2007.

16. Oda Y, Sakamoto A, Shinohara N, Ohga T, Uchiumi T, Kohno K, Tsuneyoshi M, Kuwano $M$ and Iwamoto Y: Nuclear expression of YB-1 protein correlates with P-glycoprotein expression in human osteosarcoma. Clin Cancer Res 4: 2273 $2277,1998$.

17. Fehm T, Morrison L, Saboorian H, Hynan L, Tucker T and Uhr J: Patterns of aneusomy for three chromosomes in individual cells from breast cancer tumors. Breast Cancer Res Treat 75 227-239, 2002.

18. Jurchott K, Bergmann S, Stein U, Walther W, Janz M, Manni I, Piaggio G, Fietze E, Dietel M and Royer HD: YB-1 as a cell cycle-regulated transcription factor facilitating cyclin $\mathrm{A}$ and cyclin B1 gene expression. J Biol Chem 278: 27988-27996, 2003.

19. Sutherland BW, Kucab J, Wu J, Lee C, Cheang MC, Yorida E, Turbin D, Dedhar S, Nelson C, Pollak M, Leighton Grimes H, Miller K, Badve S, Huntsman D, Blake-Gilks C, Chen M, Pallen CJ and Dunn SE: Akt phosphorylates the Y-box binding protein 1 at Ser102 located in the cold shock domain and affects the anchorage-independent growth of breast cancer cells. Oncogene 24: 4281-4292, 2005.

20. Stratford AL, Habibi G, Astanehe A, Jiang H, Hu K, Park E, Shadeo A, Buys TP, Lam W, Pugh T, Marra M, Nielsen TO, Klinge U, Mertens PR, Aparicio S and Dunn SE: Epidermal growth factor receptor (EGFR) is transcriptionally induced by the Y-box binding protein-1 (YB-1) and can be inhibited with iressa in basal-like breast cancer, providing a potential target for therapy. Breast Cancer Res 9: R61, 2007.

21. Shiota M, Izumi H, Onitsuka T, Miyamoto N, Kashiwagi E, Kidani A, Yokomizo A, Naito S and Kohno K: Twist promotes tumor cell growth through YB-1 expression. Cancer Res 68: 98-105, 2008.
22. Lee C, Dhillon J, Wang MY, Gao Y, Hu K, Park E, Astanehe A, Hung MC, Eirew P, Eaves CJ and Dunn SE: Targeting YB-1 in HER-2 overexpressing breast cancer cells induces apoptosis via the mTOR/STAT3 pathway and suppresses tumor growth in mice. Cancer Res 68: 8661-8666, 2008.

23. Tay WL, Yip GW, Tan PH, Matsumoto K, Yeo R, Ng TP, Kumar SD, Tsujimoto M and Bay BH: Y-box-binding protein-1 is a promising predictive marker of radioresistance and chemoradioresistance in nasopharyngeal cancer. Mod Pathol 22: 282-290, 2009

24. Yoshimatsu T, Uramoto H, Oyama T, Yashima Y, Gu C, Morita M, Sugio K, Kohno K and Yasumoto K: Y-box-binding protein-1 expression is not correlated with p53 expression but with proliferating cell nuclear antigen expression in non-small cell lung cancer. Anticancer Res 25: 3437-3443, 2005.

25. Hannon GJ, Casso D and Beach D: KAP: a dual specificity phosphatase that interacts with cyclin-dependent kinases. Proc Natl Acad Sci USA 91: 1731-1735, 1994.

26. Johnson LN, De Moliner E, Brown NR, Song H, Barford D, Endicott JA and Noble ME: Structural studies with inhibitors of the cell cycle regulatory kinase cyclin-dependent protein kinase 2 . Pharmacol Ther 93: 113-124, 2002.

27. Brown NR, Noble ME, Lawrie AM, Morris MC, Tunnah P, Divita G, Johnson LN and Endicott JA: Effects of phosphorylation of threonine 160 on cyclin-dependent kinase 2 structure and activity. J Biol Chem 274: 8746-8756, 1999.

28. Poon RY and Hunter T: Dephosphorylation of Cdk2 Thr160 by the cyclin-dependent kinase-interacting phosphatase KAP in the absence of cyclin. Science 270: 90-93, 1995.

29. Lu ZH, Books JT and Ley TJ: YB-1 is important for late-stage embryonic development, optimal cellular stress responses, and the prevention of premature senescence. Mol Cell Biol 25: 4625-4637, 2005

30. Murray JM, Carr AM, Lehmann AR and Watts FZ: Cloning and characterisation of the rad9 DNA repair gene from Schizosaccharomyces pombe. Nucleic Acids Res 19: 3525-3531, 1991.

31. Hirai I and Wang HG: A role of the C-terminal region of human Rad9 (hRad9) in nuclear transport of the hRad9 checkpoint complex. J Biol Chem 277: 25722-25727, 2002.

32. Lieberman HB, Hopkins KM, Nass M, Demetrick D and Davey S: A human homolog of the Schizosaccharomyces pombe $\mathrm{rad}^{+}$checkpoint control gene. Proc Natl Acad Sci USA 93: 13890-13895, 1996.

33. Komatsu K, Miyashita T, Hang H, Hopkins KM, Zheng W, Cuddeback S, Yamada M, Lieberman HB and Wang HG: Human homologue of S. pombe Rad9 interacts with BCL-2/BCL-xL and promotes apoptosis. Nat Cell Biol 2: 1-6, 2000.

34. St Onge RP, Udell CM, Casselman R and Davey S: The human G2 checkpoint control protein hRAD9 is a nuclear phosphoprotein that forms complexes with hRAD1 and hHUS1. Mol Biol Cell 10: 1985-1995, 1999.

35. Bermudez VP, Lindsey-Boltz LA, Cesare AJ, Maniwa Y, Griffith JD, Hurwitz J and Sancar A: Loading of the human 9-1-1 checkpoint complex onto DNA by the checkpoint clamp loader hRad17-replication factor C complex in vitro. Proc Natl Acad Sci USA 100: 1633-1638, 2003.

36. Volkmer E and Karnitz LM: Human homologs of Schizosaccharomyces pombe Rad1, Hus1, and Rad9 form a DNA damageresponsive protein complex. J Biol Chem 274: 567-570, 1999.

37. Lieberman HB and Yin Y: A novel function for human Rad9 protein as a transcriptional activator of gene expression. Cell Cycle 3: 1008-1010, 2004

38. Lim HH and Surana U: Cdc20, a beta-transducin homologue, links RAD9-mediated G2/M checkpoint control to mitosis in Saccharomyces cerevisiae. Mol Gen Genet 253: 138-148, 1996.

39. Yuki T, Maniwa Y, Doi T, Okada K, Nishio W, Hayashi Y and Okita Y: DNA damage sensor protein hRad9, a novel molecular target for lung cancer treatment. Oncol Rep 20: 1047-1052, 2008.

40. Peters JM: The anaphase-promoting complex: proteolysis in mitosis and beyond. Mol Cell 9: 931-943, 2002.

41. Pines J and Hunter T: Human cyclin A is adenovirus E1 Aassociated protein p60 and behaves differently from cyclin B. Nature 346: 760-763, 1990.

42. Pines J: Cell cycle: reaching for a role for the Cks proteins. Curr Biol 6: 1399-1402, 1996.

43. Yee A, Nichols MA, Wu L, Hall FL, Kobayashi R and Xiong Y: Molecular cloning of CDK7-associated human MAT1, a cyclindependent kinase-activating kinase $(\mathrm{CAK})$ assembly factor. Cancer Res 55: 6058-6062, 1995. 
44. Amati B and Vlach J: Kip1 meets SKP2: new links in cell-cycle control. Nat Cell Biol 1: E91-E93, 1999.

45. Carrano AC, Eytan E, Hershko A and Pagano M: SKP2 is required for ubiquitin-mediated degradation of the CDK inhibitor p27. Nat Cell Biol 1: 193-199, 1999.

46. Yu X and Chen J: DNA damage-induced cell cycle checkpoint control requires CtIP, a phosphorylation-dependent binding partner of BRCA1 C-terminal domains. Mol Cell Biol 24: 9478-9486, 2004.

47. Fujii T, Seki N, Namoto-Matsubayashi R, Takahashi H, Inoue Y, Toh U, Kage M and Shirouzu K: YB-1 prevents apoptosis via the mTOR/STAT3 pathway in HER-2-overexpressing breast cancer cells. Future Oncol 5: 153-156, 2009.

48. Cheng GZ, Chan J, Wang Q, Zhang W, Sun CD and Wang LH: Twist transcriptionally up-regulates AKT2 in breast cancer cells leading to increased migration, invasion, and resistance to paclitaxel. Cancer Res 67: 1979-1987, 2007.
49. Basaki Y, Taguchi KI, Izumi H, Murakami Y, Kubo T, Hosoi F, Watari K, Nakano K, Kawaguchi H, Ohno S, Kohno K, Ono M and Kuwano M: Y-box binding protein-1 (YB-1) promotes cell cycle progression through CDC6-dependent pathway in human cancer cells. Eur J Cancer 46: 954-965, 2010.

50. Evdokimova V, Tognon C, Ng T, Ruzanov P, Melnyk N, Fink D, Sorokin A, Ovchinnikov LP, Davicioni E, Triche TJ and Sorensen PH: Translational activation of Snaill and other developmentally regulated transcription factors by YB-1 promotes an epithelial-mesenchymal transition. Cancer Cell 15: 402-415, 2009. 